\title{
LAS «LIMITACIONES DE EXPRESIÓN» EN ESPAÑA DURANTE LAS DÉCADAS CINCUENTA Y SESENTA: EL EJEMPLO DE DOS ANTOLOGÍAS POÉTICAS
}

LuCía Montejo GuRRuchaga

UNED

La censura española estuvo vigente desde 1938, fecha en la que se promulga la Ley de Prensa, hasta pasada ampliamente la fecha de 1975 en que se produce la transición política y se instaura un régimen de libertades. La legislación relativa a la censura no sufrió cambios significativos durante decenios, aunque su aplicación fue evolucionando lentamente hacia una mayor permisividad - no exenta de retrocesos- a medida que iban cambiando la sociedad y el Régimen franquista ${ }^{1}$. A partir de 1975 y hasta 1981 hay constancia en el Archivo General de la Administración en Alcalá de Henares, de que había que

1 La censura dependió en los primeros momentos, en la inmediata posguerra, del Servicio de Prensa y Propaganda, en el ámbito del Ministerio de la Gobernación; pasó después a la subsecretaría de Educación Popular -Sección de censura de Publicaciones- del Ministerio de Educación Nacional. En julio de 1951 se crea el Ministerio de Información y Turismo, del que se trasladó a la Dirección General de Información, que cambiaría de nombre en varias ocasiones: Dirección General de Cultura y Espectáculos - Sección de Ordenación Editorial--, Orientación bibliográfica y Regimen Editorial en los años inmediatamente anteriores y posteriores a la transición política. En los años 70 , el expediente que los editores debían presentar llevaba el eufemístico título de *Consulta voluntariam. 
cumplir el trámite de solicitar la autorización para la publicación de todo tipo de obras.

En cuarenta años de régimen censorio se aplicó sin interrupción, unas veces con mayor y otras con menor crudeza, a todos los géneros literarios y en todas sus manifestaciones. Sólo las publicaciones dependientes de la Iglesia estaban exentas del control gubernativo. Desde sus inicios se empeño con mayor esfuerzo en las publicaciones periódicas y el ámbito de la información fue férreamente controlado por el Estado al más puro estilo absolutista.

Los censores actuaban con criterios poco precisos y, en muchas ocasiones de forma aleatoria y arbitraria. A lo largo de la dictadura no hubo uniformidad en la forma de encauzar, vigilar o censurar la actividad editorial, sino que se alternaron distintas políticas de información y propaganda dependiendo del momento político, del ministro que estuviera a la cabeza o de otras circunstancias nacionales e internacionales. Sin embargo, formaban un cuerpo que intervenía con rapidez y contumacia ${ }^{2}$. Actuaban en las obras que se publicaban en España y mantenían también un control tenaz sobre todos los volúmenes que intentaban entrar desde el exterior; era obligatorio el permiso de importación para cada una de las obras.

Toda publicación debía pasar ineludiblemente por este organismo represor y el editor tenía que rellenar un impreso en el que solicitaba «la autorización que exige la Orden de 29 de abril de 1938, y disposiciones complementarias, para la edición del libro y folleto cuyas características se indican» a continuación ${ }^{3}$. La sección de Inspección de Libros abría un expediente, al que le asignaba un número, y se le adjuntaba un informe que debería rellenar el censor al que le fuera adjudicado. En él figuraban, expresamente formuladas, las siguientes pautas: «¿Ataca al Dogma?», «AA la Iglesia?», « $i A$ sus Ministros?», « ¿A la Moral?», « «Al Régimen y a sus instituciones?», «iA las personas que colaboran o han colaborado con el Régimen?» ${ }^{4}$. Estaban preparados para evitar cualquier ataque a la religión, preservar la moral de los españoles y eludir lo que consideraran un atentado al recato y las tradiciones. Además, de-

2 En una de las INSTRUCCIONES - la sexta- que figuraban al dorso del impreso de solicitud, decfá. «Cada instancia será contestada en el plazo normal de siete dras hábiles por medio del impreso reglamentario en el que consta la resolución recafda, acompañado de un original de los presentados, que deberá recogerse en el Registro General contra el resguardo correspondiente».

${ }^{3}$ Estos rasgos eran: autor, título, editor, volumen, formato, tirada. No sólo el nombre del autor era determinante a la hora de emitir el informe, sino también que se tratara de una editorial de un determinado o marcado signo y de una tirada de muchos ejemplares. Solían ser más tolerantes con las pequerias o desconocidas colecciones y con tiradas reducidas.

4 Reproduzco literalmente las consignas tal y como figuran en el informe y mantengo, por tanto, las mayúsculas singularizadoras. 
bían velar celosamente por el sometimiento y la obediencia al sistema político, atajar la propagación de ideologías no autoritarias y marxistas, y evitar el lenguaje considerado grosero, inconveniente o malsonantes.

Estos requisitos traían de cabeza a autores y editores, que debfan tenerlos siempre presentes, acatarlos meticulosamente o eludirlos, si no querían que se les mutilara, negara o retirara la publicación. Esta situación les llevó a continuos forcejeos con los censores y a afrontar, en muchas ocasiones, procesos y multas. Además, obligó a los autores a practicar la autocensura, el control de la expresión, manejando argucias y estrategias para intentar burlar este mecanismo de control. Algunos críticos y creadores han señalado que afectó, sobre todo, a los dramaturgos y a los directores de cine, pero frente a estas opiniones optimistas nos encontramos con las de algunos poetas - una gran parte de los que sufrieron el exilio y otros como Blas de Otero, Gabriel Celaya, José Manuel Caballero Bonald, José Ángel Valente o José Agustín Goytisolo, por citar una pequeña muestra-, que sufrieron la censura de forma sistemática, con obras prohibidas, mutiladas y muchos versos suprimidos. Blas de Otero declaraba en 1976: «La censura es un obstáculo terrible, capaz de condicionar, de coartar y, en ocasiones, hasta de hacer callar. Además la censura genera la autocensura... La censura fue aprendiendo a leer y resultó que el poeta que tuviera interés por publicar en España se encontraba con el problema de que, si escribía tal y como las palabras le iban saliendo, aquello se convertía en algo impublicable. No había otra solución que la obligada de corregir los poemas...Se acaba por adquirir una práctica muy eficaz en sus argucias $^{6} \%$.

Los escritores, al no poder expresarse libremente, generarán distintos mecanismos de autocensura - figuras de transferencia semántica, de repetición y otras modalidades estilísticas - y adquirirán en muchos casos, una experiencia útil y provechosa. Se autocensuraban al no tratar determinados temas, al modificar, cambiar o suprimir un adjetivo, un sustantivo, agazapar una idea o recurrir a tal o cual imagen, juego de palabras, equívoco o figura de sustitución semántica. Todo menos el silencio, porque si el empeño de la censura era hacerles callar, el de ellos era hacerse oír.

El éxito de las destrezas que los autores desarrollan para enmascarar determinados enunciados depende de su capacidad de creación lingüística, de su

5 Manuel L. Abellán en su estudio Censura y creación literaria en España (1939-1976), Barcelona, Península, 1988, recoge distintas actuaciones de los censores en casi cuarenta años de régimen franquista.

- Suffen, Luis: *Blas de Otero con los ojos abiertos», en Reser̃a, XIII, 91, Madrid, enero 1976, 17. 
aptitud para combinar los distintos elementos - fónicos, sintácticos, semánticos, rítmicos, gráficos, métricos - del lenguaje, de su habilidad para elaborar un lenguaje necesario para su representación. Mediante procedimientos de desvío, rompiendo los artificios de previsibilidad, la linealidad del verso o del discurso, o la unidad del vocablo, creando palabras al margen de las convenciones del sistema o liberando los enlaces sintácticos, mantienen la tensión y el equilibrio, y al mismo tiempo que aseguran la eficacia estética y de sentido, estas técnicas desorientan a los censores, dificultan su trabajo y, a veces, consiguen que el poema eluda el control gubernamental.

Algunas de estas estrategias, como la utilización de anagramas, de iniciales o nombres de pila -escondiendo los apellidos delatores-, de epígrafes en otros idiomas, de las ambivalencias de determinadas figuras retóricas como la metonimia, de la habilidad y sutileza de la alusión - perfectamente inteligibles para el receptor al que el creador se dirige-, de la ruptura de las frases hechas, de la ironía, de la intertextualidad, de los puntos suspensivos, de imágenes y símbolos, de tachaduras indicando autocensura por supresión, de recurrencias fónicas, cumplieron con eficacia los fines propuestos y fueron práctica generalizada, duradera y decisiva para intentar publicar dentro de España y no tener que buscar otros cauces de publicación fuera del país, cosa que sólo conseguían los autores de más peso y con buenas relaciones, con lo que el número de lectores - siempre minoritario- menguaba sensiblemente. Solían acudir también a otras argucias, como reeditar poemas que habían recibido el beneplácito junto a otros inéditos, y sin censura previa, argumentando que tenían ya la autorización, y corriendo el riesgo de que toda la edición fuese secuestrada si el original había sido modificado o se habran introducido poemas cuya publicación había sido denegada.

Muchos autores emplearon la táctica de incluir como prólogo o introducción el estudio de un autor respetado por el Régimen como forma de proteger su contenido o daban a conocer algunos de sus poemas tachados o mutilados, o cuya publicación en libro se les había denegado, en antologfas o revistas. Era frecuente que seleccionaran algunos de los poemas que imaginaban que iban a tener problemas con la censura para que aparecieran previamente en alguna revista o en algunas antologías preparadas por críticos de reconocido prestigio, autoridad e influencia, tanteando así la posible acogida. En ocasiones, salían mejor paradas las que habían sido ideadas por críticos o especialistas de menor renombre y escasa celebridad, porque los censores no las estaban esperando. Este es el caso, por ejemplo, de la antología de María de Gracia Ifach, Cuatro poetas de hoy',

7 Madrid, Taurus, 1960. Se hicieron, sin que tuviera ningún problema, cuatro ediciones en quince años y de tiradas cuantiosas: 1960, 1965, 1969 y 1975. 
dedicada a José Luis Hidalgo, Gabriel Celaya, Blas de Otero y José Hierro. Constatamos con asombro que -y posiblemente por exceso de celo de la antóloga - se incluyen distintos poemas censurados por ella misma - y en su lugar aparece una larga línea de puntos suspensivos-, que habían sido autorizados previamente en su integridad, y al revés, poemas denegados por el órgano censor se recogen sin la menor supresión o tachadura. Incluso, en la abundante muestra de cada poeta, hay composiciones entonces inéditas, como en el caso de Hidalgo, que no fueron recogidas en libro y, por lo tanto, prácticamente inencontrables. Es una muestra más de la arbitrariedad con la que obraba este instrumento de control.

Voy a ceñir mi análisis sobre el comportamiento de la censura a dos antologías poéticas, que se publican en un corto espacio de tiempo, y que recogen una muestra significativa de la poesía que entonces se estaba haciendo y da cuenta de los jóvenes poetas que estaban empezando a escribir y a publicar. Se trata de la Antología de la Nueva Poesía Española, publicada por Gredos en 1958 y de El tema de España en la poesía española de posguerra, publicada por la editorial Revista de Occidente en 1964. Ambas fueron preparadas y prologadas por José Luis Cano. Muchos de los poetas que aparecen en la primera, repiten en la segunda; la primera eludirá la inspección sin dificultad, y la segunda le planteará, como veremos, serios problemas. El propio Cano, en la «Nota a la segunda edición» de El tema de España en la poesía española de posguerra ${ }^{8}$ señala que «la primera edición de este libro fue publicada, no sin graves problemas de censura».

José Luis Cano habfa recogido, tal y como anunciaba en el prólogo de su Antología de la Nueva Poesía Española, una amplia muestra de la poesía realizada en España por las últimas promociones poéticas a partir de 1936; son cuarenta y seis poetas que representan, por tanto, las distintas tendencias y características de la poesía de preguerra y posguerra. Empieza por una extensa serie de poemas de los componentes de la generación del 36 -encabezada por Miguel Hernández-, sigue con algunos representantes de la poesía «desarraigada», «tremendista» - cuyo órgano de expresión fue la revista leonesa Espadaña animada por Victoriano Crémer y Eugenio de Nora-, de su antagonista Garcilaso, y de la tendencia realista o histórica -etiquetada como poesía social - con Blas de Otero y Gabriel Celaya entre otros nombres. Finaliza la antología con algunos poemas de los que más tarde serán etiquetados con el marbete de «poetas del conocimiento» o segunda generación de posguerra. Advierte el antólogo que están ausentes de esta selección los po-

Col. Temas de Espanfa, Madrid, Taurus, 2." ed. 1978, 33. 
etas de la España peregrina y señala que espera subsanar esta ausencia en la segunda edición.

La solicitud para la publicación de esta antología, de fecha 4 de marzo de 1958 , la presenta A. Hurtado en nombre de Gredos, con las siguientes características: obra de 386 páginas, con tirada de 3.000 ejemplares y precio de 90 pesetas, en la colección Antología Hispánica. Se le asigna el expediente número 1089-58 y está archivado en el A.G.A ${ }^{9}$. Al día siguiente, con la prontitud habitual y bajo el acostumbrado anonimato, alguien escribe esta frase: «Pasa al lector $14^{10} \%$, que emite el siguiente informe:

«Poesfa moderna, temática variada. Poetas contemporáneos más o menos relacionados con los premios Adonais. No sé qué otra cosa decir, sino que no he encontrado en ellas nada que se oponga a su autorización, y por lo tanto PROCEDE SU AUTORIZACION.»

La firma es clara en esta ocasión, Javier Dietta. La fecha del informe es del 21 de marzo de 1958.

José Luis Cano era ya en aquellos momentos un poeta, crítico y escritor de prestigio. Participaba, animaba y dirigía muchos de los proyectos literarios que llevaron al restablecimiento de esta actividad ya en los primeros años cuarenta ${ }^{11}$ y además, llevaba entre manos la creación de una intensa obra poética,

- Tanto este expediente, como el que analizaré a continuación, y todas las cartas, informes, solicitudes y notas varias archivadas con él, es la primera vez que se hacen públicos. Transcribo esta documentación tal y como se ha conservado durante tres decadas, sin añadir ni quitar una coma.

${ }^{10}$ Los censores - lectores en el argot del ministerio- estaban organizados por calegorias que iban desde el personal administrativo hasta el Personal técnico, censores propiamente dichos. Sus categorias iban desde el jefe de lectorado, el lector especialista, el eclesiástico, lector fijo, hasta el lector eventual y pluriempleado. Había personas de gran prestigio, catedráticos, políticos y otros puestos adscritos o muy cercanos al régimen de Franco, y personas de escasa formación cultural. Abellán en el estudio citado, incluye la *Nómina de censores afectos a la Inspección de Libros (Madrid), correspondiente al ano 1954m. Ademas, se identificaban por un número y, por lo general, la firma que aparece en el informe suele ser ilegible, aunque después de consultar, leer y releer docenas de expedientes, muchas de ellas se le hacen familiares al estudioso y van poco a poco desvelando a su propietario.

"La colección Adonais, que empieza su andadura en 1943, fue promovida por José Luis Cano y fue una publicación relevante e indispensable de la poesía española de posguerra. Se propuso, en los primeros momentos, ser portavoz y servir de canal literario a la poesía que renacía tras la guerra civil y a aquellos jóvenes poetas que debían conformarse con ver algunos de sus poemas en las revistas ante la inexistencia de un mercado poético normalizado. Juan Guerrero asumí la función de editor y José Luis Cano las de director. El primer ejemplar de la colección, Poemas del toro de Rafael Morales, vio la luz en la primavera de 1943 y a partir de esa fecha, casi todos los más significativos poetas publicaron en ella. Además, supo abrirse a la pluralidad de tendencias poéticas y acoger 
que había iniciado en el entorno de la revista Litoral. Sabía muy bien cuál era el funcionamiento del cuerpo de censores, por haberlo padecido ya, y manejaba con holgura sus mecanismos.

El censor redacta un informe para salir del paso. Una antología tan significativa como esta, que recoge muchos de los poemas relevantes de esa década, que algunos de ellos han tenido serios encontronazos con la censura, recibe, sin embargo, estas desinteresadas e imprecisas líneas. El respaldo de una gran editorial no era un seguro, pero la inhibición del censor no se comprende. Cano había seleccionado composiciones de distintos poetas que habían tenido y seguirían teniendo problemas con el cuerpo de censores, doce habían recibido el premio Adonais, y varios de ellos estarán entre los grandes poetas españoles de posguerra. Algunos figuraban en antologías que habían topado con la censura, como la Antología Consultada de la Joven Poesía Española, de Francisco Ribes de 1952, que recogió la tendencia histórica o social de posguerra, de gran trascendencia, y en Veinte años de poesía española, de José María Castellet, de 1960, por nombrar solo dos, y estaban teniendo complicaciones, en aquellas mismas fechas, con algunas de sus obras. Por ejemplo, a la editorial Losada, de Buenos Aires, se le había denegado en 1960 la importación de la Poesía urgente, de Gabriel Celaya; Blas de Otero había conocido ya los rigores de la censura desde 1949 con Ángel fieramente humano y estaba teniendo problemas en aquellos mismos meses con su libro Ancia, Vicente Gaos y otros los tendrán un poco más tarde, como José Agustín Goytisolo, Caballero Bonald o José Ángel Valente. Sin embargo, el censor no se para a comprobar si algunos de estos poemas figuran entre las obras mutiladas, denegadas o tachadas de estos autores. Fallaba la comunicación entre el cuerpo de censores y gracias a ello muchas obras escaparon.

Del poeta Blas de Otero recoge Cano en esta Antología de la Nueva Poesía Española algunos poemas pertenecientes a Ángel fieramente humano (1950), Redoble de conciencia (1951) y Pido la paz y la palabra (1955), es decir, poemas de su etapa existencial y las primeras muestras de su poesía histórica o social. Comprobamos que hay varios poemas, tanto de Angel fieramente humano como de Redoble de conciencia, que le dieron problemas la primera vez que los presentó a censura y cada vez que pretendió incluirlos en sus anto-

a autores de criterios bien dispares. Con el premio homónimo que se concedía paralelamente, y que se sigue otorgando anualmente, sin interrupción, por Ediciones Rialp S.A., premia una obra inédita que pasa a editar la colección Adonais. Bajo la influencia de Vicente Aleixandre, seleccionó y galardonó a poetas consagrados, a jóvenes promesas y llevó a cabo traducciones de clásicos contemporáneos. En 1963 José Luis Cano cesó en sus funciones y Luis Jiménez Martos tomó a su cargo la colección en el número 209 sustituyéndole. 
logías. En 1949 Blas de Otero había concursado al Premio Adonais con Ángel fieramente humano y el libro fue excluido; el jurado alegó razones de heterodoxia religiosa y adujo que algunos de los poemas estaban en desacuerdo con el dogma católico. Estos poemas tienen como núcleo su pasada vivencia religiosa, su lucha con Dios, apoyada en otros temas como el amor, la soledad o la muerte y en ellos, Dios se le presenta al hombre como el Yahvé del Antiguo Testamento; es la imagen terrible de un Dios implacable, distante, ajeno al sufrimiento del hombre, silente. Esta lucha se expresa con un léxico religioso, fórmulas litúrgicas, citas bíblicas y otras recurrencias a textos sagrados ${ }^{12}$. El vocabulario religioso, imágenes, símbolos, alegorías y citas bíblicas las utiliza el poeta con una clara intencionalidad; se trata del propósito deliberado de volver a lo humano el lenguaje religioso. Se crea así una subversión del léxico religioso desde la misma lengua poética. Por ello, el censor escribe en el informe que «le es difícil apreciar, si el nombre de Dios que constantemente aparece en ellas, es para venerarle o al contrario», por lo que llama la atención de la superioridad sobre distintos poemas. El libro fue publicado por Insula con distintas tachaduras y supresiones.

Unos meses más tarde, ganó con Redoble de conciencia el recién creado Premio Boscán 1950 otorgado en Barcelona por el Instituto de Estudios Hispánicos que lo edita en 1951. Este libro es continuación del anterior en sus temas y en sus formas. Es un libro más solidario que Ángel fieramente humano porque en él se refleja el impacto que le produjo al poeta los estragos que la Segunda Guerra Mundial cauś́ en Europa. El propio Delegado Provincial de Educación y Propaganda en Barcelona, José Pardo, escribió a Juan Beneyto ${ }^{13}$ el 8 de noviembre la carta siguiente:

«Con fecha de septiembre último y por expedición de esta Delegación Provincial n. 214 , fue remitida a esa Delegación General, en solicitud del permiso de edición y circulación, la obra original de Blas de Otero titulada Redoble de conciencia. Como sea que dicha obra es

12 Para una mayor información sobre el empleo de los textos sagrados en Blas de Otero se pueden consultar: Blas de Otero. Poesía escogida, introducción, selección y notas de Sabina de la Cruz y Lucía Montejo, Barcelona Vicens Vives, 1995 y mi articulo «El vínculo de Blas de Otero con las Sagradas Escriturasm, Zurgai, (Que trata de Esparia: Especial Monográfico), Bilbao, noviembre 1988, 102-106.

13 Juan Beneyto Pérez, ligado al falangismo y con importante participación en sus órganos de expresión, fue Director General de Prensa, Director de la Escuela Oficial de Periodismo y Presidente del Consejo Nacional de Prensa. Escritor y catedrático de la facultad de Ciencias Políticas de la Universidad de Madrid y profesor de la Escuela Judicial, fue subdirector de los cursos de Periodismo de la Universidad Menéndez y Pelayo de Santander. Ocupó otros cargos y escribió más de una docena de libros sobre determinados aspectos políticos y jurídicos. 
la favorecida con el «Premio Boscán», otorgado por el Instituto de Estudios Hispánicos de Barcelona, quien tiene gran interés en su edición, mucho te agradeceré, querido Beneyto, procures que el trámite de su autorización sea lo más rápido posible».

Beneyto le contesta el 24 diciéndole que el libro ha sido autorizado y se ha remitido la correspondiente tarjeta el día 16. El ejemplar escrito a máquina que se adjunta, y que está archivado en el A.G.A. junto al expediente n..$^{\circ} 5365$ 50 , no tiene ninguna tachadura ni el más mínimo rastro de bolígrafo y alguien escribió en la portada de cartulina color malva: «Premio Boscán 1950». Me atrevería a decir que, al ir amparada por un premio oficial otorgado por una institución de prestigio $\mathrm{y}$, avalada además, por un alto funcionario del Ministerio de Educación y Propaganda, la obra no fue leída o lo fue de manera superficial, porque en este ejemplar se incluyen algunos de los poemas que le habían dado y le darán a Blas de Otero, años más tarde, muchos quebraderos de cabeza. Este es el caso del poema «Déjame» que, por motivos de censura, pasará a llamarse en Ancia, «Lástima». Este es el soneto:

«Me haces daño, Señor. Quita tu mano

de encima. Déjame con mi vacío,

dejame. Para abismo, con el mío

tengo bastante. Oh Dios, si eres humano,

compadécete ya, quita esa mano

de encima. No me sirve. Me da frío

y miedo. Si eres Dios, yo soy tan mío

como tú. Y a soberbio, yo te gano.

Déjame. ¡ Si pudiese yo matarte, como haces tú, como haces tú! Nos coges

con las dos manos, nos ahogas. Matas

no se sabe por que. Quiero cortarte

las manos. Esas manos que son trojes

del hambre, y de los hombres que arrebatas.»

Este soneto había aparecido por primera vez en Espadaña ${ }^{14}$ y Crémer lo colocó a toda plana. La queja del yo poético que se inicia quedamente, termina con

14 Número 47, 1950, pág. 95. Otero tenía la costumbre, como hicieran otros muchos poetas, de mostrar algunos poemas inéditos en ciertas revistas, no sólo para dar a conocer algunas muestras de lo que en aquellos momentos hacía, sino para sondear el comportamiento que con ellos tenía la 
un grito de rebeldía frente a un Dios implacable, que no se ablanda ni cede en su rigor. Victor García de la Concha ${ }^{15}$ señala que aquellos versos fueron el detonante que, unido a otras audacias, precipitó el fin de la revista. Crémer tuvo que presentarse y defenderse ante un tribunal eclesiástico y «publicar una nota aclaratoria y de rectificación en el diario católico».

«Lástima» era el nuevo título que Otero había dado al soneto «Dejame». Para protegerlo, además de cambiarle el título, le añadió como epígrafe - tal y como aparece en la antología de Cano- la siguiente cita de San Juan de la Cruz: «Cosa de grande maravilla y lástima que sea aquí tanta la flaqueza e impureza del ánima que siendo la mano de Dios de suyo tan blanda y suave, la sienta el alma aquí tan grave y contraria». El poeta, en una larga carta dirigida al Director General de Información el 19 de febrero de 1958, sale en defensa de este soneto alegando que «es profundamente religioso y con expresiones análogas a las que pueden encontrarse en la Biblia o en algunos de los místicos», pero sus explicaciones no convencieron al censor que le negó la publicación.

Sin embargo, este y otros poemas considerados entonces conflictivos, vieron la luz en esta antología sin el menor contratiempo ${ }^{16}$.

El 29 de octubre de 1963 la editorial Revista de Occidente solicita la autorización para imprimir la antología titulada El tema de España en la poesía española de posguerra17 de la que es autor José Luis CANO GARCIA DE LA TORRE, con un volumen de 250 páginas y una tirada de

censura. La revista Espadaria, nacida en León, en la que Blas de Otero publicó en varias ocasjones - la primera en el número 37 (1949) - había conseguido la autorización para su publicación de la Delegación Nacional de Prensa y Propaganda en mayo de 1944 y tenía como redactores a Victoriano Crémer, Antonio G. de Lama y Eugenio de Nora. En ella se llevó a cabo la controversia entre tremendistas y rehumanizadores, por un lado, y garcilasistas y neoclásicos, por otro. Encabezó la rehumanización poética y contribuyó a la progresiva recuperación del grupo poetico del 27. Se vinculó a Neruda, Valery, Aragon, dedicó un número homenaje a César Vallejo e intentó conducir la rehumanización hasta el compromiso.

15 Poesia española de 1935 a 1975. De la posguerra a los años oscuros. 1935-1944, vol. I, Madrid, Cátedra, 1987, 481.

16 Algunos especialistas en esta materia han considerado que la etapa de Gabriel Arias-Salgado en el Ministerio de Información y Turismo, desde 1951 a 1962 - hombre de ortodoxia doctrinal y polftica- fue de dureza. Se ha aludido siempre a su intransigencia y a su celo por la salvaguarda de la moralidad, las buenas costumbres y los valores religiosos, y en los círculos políticos se comentaba: *Con Arias todo tapadow. Sin embargo, y en muchos casos, la etapa de 1962 a 1969 en la que Manuel Fraga Iribame desempeño el cargo de Ministro de Información y Turismo, considerada de aires aperturistas porque fue el que impulsó los trabajos que venían desarrollándose para la elaboración de la nueva ley de prensa, no disminuyó la presión que venía ejerciendo la censura y, en muchos casos, se hizo más rigurosa.

17 Será reeditada por Taurus en 1979 en su colección «Temas de España». 
2.000 ejemplares. Se le asigna el expediente $n .{ }^{\circ} 6156-63$ y está archivado en el A.G.A.

Según indica el antólogo en la introducción, el tema de España ha sido abordado en nuestra literatura desde todos los géneros y es un motivo recurrente en la poesía desde el Siglo de Oro hasta la lírica contemporánea. Aporta ejemplos sobrados desde la «Oda a Santiago» de Fray Luis de León, de la lírica barroca - con muchas composiciones que nos ofrecen una imagen dolorida y triste de la decadencia española-, en Jovellanos y Meléndez que cantan con acento patético la situación española tras la guerra de la Independencia. Apunta cómo con la irrupción del romanticismo, los poetas cantarán a la patria inseparablemente de la libertad y con acento apasionado. La pérdida de las colonias y la guerra con los Estados Unidos hizo que muchos poetas recrearan esta trágica situación. El tema de España va a ser casi obsesivo en dos poetas del 98: Unamuno y Machado. Señala Cano que la guerra civil va a determinar un cambio en la evolución de la poesía y sobre todo en la situación intelectual y moral del escritor. En uno y otro lado de las trincheras se escribirán poemas a la patria, y los que marchan al exilio verterán en sus versos la nostalgia, la amargura y la hostilidad. En la década de los cincuenta, con el resurgimiento de la poesía social, el poema será reflejo de unas circunstancias determinadas en una patria también determinada. Advierte Cano que, aunque es una antología temática, no se limita a la poesía preocupada, sino que se extiende también a la España física. Añade que ha prescindido de toda poesía política, es decir, «de la que pone una clara intención de propaganda política, sea la que fuere ${ }^{18}$ y de la poesía escrita en otras lenguas peninsulares. Se trata de un largo prólogo con valoraciones y explicaciones comprometidas, que recibió algunas tachaduras.

En la selección de poetas contemporáneos que Cano incluye, figuran algunos de la generación del 98, del grupo del 27, de la generación del 36 y de los poetas de posguerra terminando por los jovenes poetas del conocimiento, que estaban en las listas de los que habían padecido una fuerte represión.

Cinco días después de la entrega de la solicitud en el Ministerio de Información y Turismo, Dirección General de Información, Sección de Orientación Bibliográfica, Maximino Batanero - lector fijo y el número 21 en aquellos momentos-, emite el siguiente informe:

18 Desde algunos sectores de la prensa y las publicaciones periódicas se le achacó a Cano la omisión de la poesía política ya que, y en especial, entre los más jóvenes había abundantes composiciones de intención testimonial y política de variado signo. Puede verse al respecto el artículo de F. Delgado en Reseria, tomo III, 1964, 128-130. 
*Antologia de poemas sobre el tema de España y la patria, vista a través de las últimas generaciones. Junto a una corta selección de cantos y descripciones de España, el cuerpo principal son temas amargos, quejas de España y de la España partida, debidos en su mayoria a emigrados y poetas de izquierda. Sin embargo, se rehuye cuidadosamente todo ataque directo al Movimiento y sus instituciones, toda poesía política propiamente dicha; solo frases sueltas y símbo los, constituyen la base física que transparenta su implicación ideológica. Su dolor de la patria recogido aquí es justificable - la lucha, la admiración, con tradictoria - el deseo de amar a España hasta odiarla.

Hasta qué punto es tolerable esta consagración y difusión de nombres poco gratos a la situación mostrando solo la cara «visible» y hasta dónde se concreta su descontento de la España real, es difícil de delimitar.

Con estas salvedades, propongo la autorización con tachaduras en págs. X a XI, XIII, XVIII, 34, 58, 83, 137 a 139, 142-145 a 147-148149-165-166-174 y quizás XVII. 142 a 143-151 a 153-162-172 a 174175 y 176 .

Como podemos comprobar son muchas las páginas que entretienen el lápiz rojo del censor y van a ser pocos los escritores de esta selección que salven íntegramente sus poemas. Incluso tendrán problemas en esta ocasión poetas que no los habían tenido antes.

Se le comunica al editor este desaguisado y José Luis Cano, acostumbrado a batallar con la censura, escribe con fecha 8 de febrero de 1964 a Carlos Robles Piquer, Director General de Información en aquellos momentos, exponiéndole detenidamente los motivos de su enérgica protesta. Estas son sus palabras:

*Como poeta y antólogo de poetas - y, sin modestia, como uno de los que más han trabajado desde hace 25 años para la mayor gloria de nuestra poesía-, me duele que el censor haya mutilado mi antología, prohibiendo algunos hermosos poemas cuya publicación no pensé en ningún momento que fuese peligrosa, quizá porque a mí, como poeta, la poesía nunca me lo parece. Como no hay otro remedio, me resigno a ello, aunque quisiera llamar su atención sobre dos aspectos de la decisión del censor, en los que, me parece, éste ha llevado demasiado lejos su celo censorio.

El primero se refiere a la prohibición del poema de José Hierro «Canto a Españas, del que le adjunto copia, y que pertenece a un libro - Quinta del 42- publicado hace años por la Editora Nacional, de ese Ministerio, y además galardonado oficialmente, y reproducido mil 
veces en revistas y antologias. ¿Qué sentido tiene prohibirlo, cuando su intención es absolutamente pura, es decir exclusivamente poética, y cuando su autor, José Hierro, es colaborador frecuente de tareas y publicaciones de ese Ministerio? ¿Para que irritar, con esa decisión absurda, a un gran poeta como José Hierro?

El otro aspecto se refiere a la prohibición de todas las citas de la parte III de la Antología (le adjunto también copia). Me parece que aquí también el censor ha extremado su celo, al censurar nada menos que a Lope de Vega, Juan del Encina, el autor anónimo del «Poema de Fernán González», el Padre Feijó, Larra, Lord Byron y César Vallejo. Como cada parte lleva al frente una serie de citas, el eliminar las de la tercera parte rompe la armonía y estructura del libro, detalle importante para mí. ¿No es posible que respeten, por lo menos, las citas de Lope, Feijoo, el Poema de Fernán González, Juan del Encina y Larra? Todas esas citas son archiconocidas, $y$ han sido reproducidas mil veces.

En el caso de que quiera usted acceder a lo que le pido -por lo que de antemano le doy las gracias- le agradeceré dé las órdenes oportunas para que se comunique a la editorial Revista de Occidente.

Un cordial saludo de su affmo. amigo. Fdo: José Luis Cano.

El 21 de febrero Carlos Robles Piquer contesta personalmente a José Luis Cano la carta siguiente ${ }^{19}$ :

Mi estimado amigo:

Contesto a la suya del día 8 de Febrero para decirle que no veo inconveniente en que se publiquen, en la Antología del tema de España en la Poesía Española Contemporánea que Vd. ha realizado y que va a publicar la Revista de Occidente, el poema de José Hierro titulado "Canto a España» ni las citas de la parte tercera de la Antología que Vd. copia ${ }^{20}$.

19 Conviene recordar que una de las reglas recogidas en las INSTRUCCIONES que debian seguir autores y editore la número ocho, decía textualmente: «Toda instancia vendrá dirigida al Director General de Prppaganda y nunca a nombre de ningún funcionario del Servicio». Las cartas particulares sobre publicación de obras enviadas a un funcionario no serán contestadas, dándose por no recibidas. Estas instrucciones se llevaban a rajatabla con muchos autores, pero estos desvíos de la norma demuestran la importancia de ciertos editores y antólogos.

20 Las citas de la discordia, que recojo a continuación, que Cano adjuntó al original para que abrieran la «Parte tercera» de la Antologia, son las siguientes: «!Ay dulce y cara España,/madrastra 
En este sentido, lo digo hoy a la Sección de Orientación Bibliográfica para que lo comunique a la Editorial de la Revista de Occidente.

Si tiene Vd. alguna otra observación que hacer, le ruego me lo comunique y la estudiaré con todo interés.

En conjunto, la impresión que su antología me produjo cuando la leí rápidamente, es la de que Vd. ha forzado lo que podríamos llamar la vertiente negra del tema español en nuestra propia poesía rehuyendo de una manera general lo que podriamos llamar, según una cita muy conocida, la poesía que construye. Comprendo que Vd., como antólogo y como poeta, es perfectamente capaz y perfectamente libre para efectuar su propia selección, pero me permito pensar que aquel criterio un tanto pesimista perjudica a la propia Antologia, elimina a algunos poetas importantes que se han ocupado de Espafía con una vision más positiva y determina la inclusión, quizás excesiva, de poemas de muy relativo valor literario.

En todo caso, quedo en espera de cualquier nueva noticia suya sobre el particular y aprovecho la ocasión para enviarle un cordial saludo.» Firma Carlos Robles Piquer.

Entre la documentación que aparece junto al expediente hay una hoja escrita a máquina, dirigida al Sr. Benitez, que dice: «Para la Sección de Orientación Bibliográfica». Lleva el sello de Registro de entrada pero no tiene fecha ni firma. Se le adjunta otra hoja escrita a máquina encabezada por la siguiente frase: «Figuran en la obra anterior y no en la nueva» y se reseñan estos poemas:

pág. 60 .- SONETO de Unamuno.

pág. 61 .- CUANDO ERA PRIMAVERA de Emilio Prados.

pág. 64 .- IMPRESIONES DEL DESTIERRO, de Luis Cernuda.

pág. 135 .- CANCIÓN DEL QUIEN de Jesús López Pacheco.

de tus hijos verdaderos,/y con piedra extraha/piadosa madre y huesped de extranjeros;», de Lope de Vega. «Sehor, ipor los nuestros pecados/non destryas a Espania!», Poema de Femán Gonzalez. «Triste Espafia sin ventura,» Juan del Encina.» El descuido de Espahia lloro porque el descuido de España me duele», Feijoo.» Aquí yace media Espanta; murio de la otra media», Larra.» ¡Ah Spain, how sad will be thy reckonning-day!», Lord Byron. «España, aparta de mí este cáliz», César Vallejo. «Salí del llanto, me encontré en España», Miguel Hernández. A pesar de las muestras de magnanimidad del Director General, tuvo que suprimir las citas del Poema de Fernán González y de Lord Byron. En su lugar aparece la de Villamediana «Como madrastra, España me destierra». 
pág. 142 .- SONETO de José Bergamín.

pág. 152 .- MADRE ESPAÑA de Jesús López Pacheco.

pág. 157 .- EL HACHA de León Felipe.

pág. 192 .- LA GUERRA de José Agustín Goytisolo.

pág. 192 y 193.- EL ÚLTIMO VIAJE de Aquilino Duque.

Son los poemas definitivamente denegados después de muchos acomodos y ajustes. En un primer momento, el fallo que emiten los censores afecta a una treintena de poemas, es decir, a casi la tercera parte del libro, y los poetas censurados en algunos de sus poemas son: Unamuno, Rafael Alberti, José Bergamín, Emilio Prados, Luis Cernuda, León Felipe, Ramón de Basterra, Jesús Lopez Pacheco, Victoriano Crémer, Blas de Otero, Jaime Gil de Biedma, José Agustín Goytisolo, Leopoldo de Luis, Marcelo Arroita-Jaúregui, Carlos Sahagún y Aquilino Duque.

Empieza entonces el forcejeo con los distintos censores y según pasa el expediente por las distintas manos y va recibiendo recomendaciones y presiones, los poemas a suprimir se acaban reduciendo a nueve, que son los que se recogen en la hoja suelta anterior. Faltan documentos e informes, que han dejado rastros en los márgenes de algunas de las cartas.

Así, el día 15 de abril de 1964, J. Ortega, director de las Ediciones de Revista de Occidente S.A., escribe a Carlos Robles Piquer la siguiente carta:

Mi querido amigo:

Le adjunto maqueta del libro de José Luis Cano tal y como ha quedado después de las supresiones que Vd. me indic6.

Le ruego que una vez comprobado por $\mathrm{Vd}$., autorice el expediente $n^{\circ} 6.156$ de fecha 29 de octubre 1963 suprimiendo en él lo que no va en esta maqueta o más simplemente devolviéndome esta maqueta autorizada.

Dado el tiempo transcurrido desde la fecha de la solicitud, le agradecería la mayor rapidez posible en darme la autorización definitiva.

Le saluda muy cordialmente. Fdo. J. Ortega.

En el margen izquierdo de esta carta, en letra manuscrita, alguien ha escrito lo siguiente: «Tómese este escrito como declaración oficial, por parte del editor, de haber efectuado las supresiones ordenadas por el Ilmo. Sr. Director 
General. Faltan historialillos de Dietta y Turienzo enviados en su día al despacho del Director General». Una firma ilegible y una fecha: 12-V-64. AUTORICESE ${ }^{21}$.

Son siete meses de duras negociaciones, de tira y afloja que soportan algunos y que minan las esperanzas y el entusiasmo de otros muchos. De Jesús López Pacheco había seleccionado Cano dos poemas, «Canción del quien» y «Madre España». Como no pudo llegar a ningún acuerdo, este escritor -adscrito a la poesía social y a la corriente del realismo social con su primera novela- tuvo que ser eliminado de la antología. Sin embargo, y contra lo que cabía esperar, cedieron con los poemas de Blas de Otero. Cano había seleccionado doce del escritor vasco correspondientes a sus libros Pido la paz y la palabra (1955), En castellano (1959) y Que trata de España (1964). A En castellano, tras innumerables problemas de censura, se le deneg6 la publicación y fue editado en París, en edición bilingüe y con el título de Parler clair ${ }^{22}$ y en aquellas mismas fechas estaba sufriendo un auténtico calvario con su libro Que trata de España y la censura acabará eliminando más de un tercio de los poemas ${ }^{23}$.

Cano sabía muy bien la situación en la que se encontraban estos libros de Blas de Otero y, sin embargo, decidio incluir en su antología una amplia muestra. El ejemplar de la antología archivado en el A.G.A. junto a la documentación que he mostrado, revela el proceso que siguieron muchos poemas, entre ellos los del poeta vasco. Aparecen mutilados los poemas «Torno» y «En castellano» e íntegramente tachados con un aspa «Otoño» e «Hija de Yago»; el primero de Que trata de España y el segundo de Pido la paz y la palabra. Sin embargo, el descontento y la disconformidad del editor y del antólogo, que hicieron públicos, salvó estos poemas en su totalidad, que ya tenían una larga historia de tropiezos y denegaciones. Veamos, al menos, uno de ellos. Se trata de «Hija de Yago» de Pido la paz y la palabra.

21 El expediente ha pasado, por tanto, al menos por tres censores además de por las manos del mismísimo Director General de Información que, como hemos podido comprobar en su carta, ha sido tan duro o más con la antología que los demás miembros del cuerpo. Se habla de los «historialillos» de Dieta y Turienzo, ambos de larga trayectoria censoria. Dieta, lector de poesfa, cuyo nombre se refleja en muchos de los expedientes de distintos poetas durante dos décadas y Álvaro Turienzo, otro asiduo y especialista censor en las mismas decadas. He constatado, y es un hecho bastante común, que faltan documentos en muchos expedientes y es lamentable.

22 Traducida y prolongada por Claude Couffon, Paris, Pierre Seghers, 1959. La primera edición en español la lleva a cabo la Universidad Autónoma de México en 1960. En España tendrá que esperar hasta 1977, que será publicada por Lumen en Barcelona.

${ }^{23}$ Unos meses más tarde se publicará íntegramente en Paris, Ruedo Ibérico, 1964 y casi en simultáneo en La Habana, Editora del Consejo Nacional de Cultura, 1964. 
«Aquí, proa de España preñadamente en punta; aquí, talón sangrante del bárbaro Occidente; áspid en piedra viva, que el mar dispersa y junta; pánica Iberia, silo del sol, haza crujiente.

Tremor de muerte, eterno tremor encarnecido, ávidamente orzaba la proa hacia otra vida, en tanto que el talón, en tierra entrometido, pisaba, horrible, el rostro de América adormida.

¡Santiago, y cierra España! Derrostran con las uñas y con los dientes rezan a un Dios de infierno en ristre, encielan a sus muertos, entierran las pezuñas en la más ardua historia que la Historia registre.

Alángeles y arcángeles se juntan contra el hombre. Y el hambre hace su presa, los túmulos su agosto.

Tres años: y cien caños de sangre abel, sin nombre... (Insoportablemente terrible es su arregosto.)

Madre y maestra mía, triste, espaciosa España. He aquí a tu hijo. Úngenos, madre. Haz habitable tu ámbito. Respirable tu extraña paz. Para el hombre. Paz. Para el aire. Madre, paz.»

Este poema vio la luz por primera vez en el estudio de Alarcos ${ }^{24}$, y dos meses después salió en Pido la paz y la palabra ${ }^{25}$, pero el autor lo había sometido a autocensura para que pasara el control gubernamental. Había suprimido la última parte del octavo alejandrino («el rostro de América adormida»), y había eliminado el primero del cuarto cuarteto («Alángeles y arcángeles se juntan contra el hombre») poniendo en su lugar una larga línea de puntos suspensivos. Los repuso en $1960^{26}$ y no volverá a recogerlo, ni a presentarlo a inspección autocensurado en ninguna otra ocasión.

24 Emilio ALARCOS LLORACH: La poesía de Blas de Otero, Oviedo, Edición de la Universidad de Oviedo, 1955. Tomo el dato de Sabina de la CRUZ: Blas de Otero. Contribución a una edición crítica de su obra, Universidad Complutense, 1983, Tomo II, 990.

25 Torrelavega (Santander), ed. Cantalapiedra, 1955. Esta colección hizo desde sus inicios una apuesta por la poesía joven. A lo largo de los años cincuenta reeditó Los muertos de José Luis Hidalgo, una antología de Jose Hierro, Metropolitano -el primer libro de poesía de Carlos Barral-y Conjuros de Claudio Rodríguez. Consiguió un rápido prestigio, a pesar de publicarse lejos de los habituales circuitos de poesía.

26 OTERO, Blas de: Con la inmensa mayoría. (Pido la paz y la palabra. En castellano), Bue. nos Aires, Losada, 1960. 
Sabina de la Cruz señala que debajo de «alángeles»" ${ }^{27}$ (lexema inexistente) había otra palabra menos inocente: «falanges» ${ }^{28}$. Blas de Otero estaba denunciando la connivencia durante la guerra civil de las dos fuerzas que sostuvieron la «cruzada»: la Iglesia y la Falange, pilares en los que se apoyó la construcción de la nueva sociedad franquista. Intentar la publicación de estas palabras en aquellos momentos era un suicidio, porque a pesar del disfraz, consistente en alterar o cambiar un sonido por otro similar o contiguo, se puede recomponer la palabra solapada. Son otra forma de neologismo, atributo constante de su poesía y siempre abundantes y sistemáticos. Sobre el molde de «enterrar» crea «encielar»; si el primero significa «meter bajo tierra», el neologismo formado por contagio será «meter en el cielo», a la fuerza, a los muertos.

Hay en este poema algunas claras presencias intertextuales, como la de César Vallejo en «España aparta de mí este cáliz», de Poemas Humanos y, al fondo, fray Luis de León, uno de sus autores predilectos, en el primer alejandrino del último serventesio en el que ha fundido su endecasílabo «a toda la espaciosa y triste España» de la Oda «Profecía del Tajo».

Era difícil aunar el principio de poeticidad y el de recepción en aquellas circunstancias políticas y mantener el equilibrio entre decir y callar, entre recato y osadía; había que construir, en ocasiones, un referente unívoco que originara una pluralidad de sentidos y que implicara al receptor en el proceso del enunciado. Pero, al mismo tiempo que esos mecanismos textuales escondían ciertos signos para unos, debían ser transparentes para otros. Esto les impuls 6 a desarrollar formas innovadoras a través de transgresiones y desviaciones de sentido, a reforzar las posibilidades expresivas del lenguaje poético.

${ }^{27}$ Esta es una estrategia para burlar a la censura que Blas de Otero utiliz6 en ocasiones. Por ejemplo, en el poema «No salgas paloma, al campow de En castellano, escribe: «Cómo decir.../Espumalibre. Violentas/carcajadas... Cómo decir añil, ayer/morada...» Bajo el sustantivo kespuma» se esconde «España», y el color de la bandera republicana en el pasado -el morado-, contrasta con el azul de los falangistas en el presente. Denuncia veladamente la falta de libertad en la Espaf́a de la posguerra y la incidencia que esa situación tenfa en la conciencia individual y colectiva. Otro ejemplo muy llamativo lo encontramos en «Aire libre» del mismo libro. Dice: «Todo lo que sea salir/ de casa, estomudar de tarde en tarde,/ escupir contra el cielo de los tundras/y las medallas de los similares...m. En estos dos últimos versos hay una falta de concordancia en el género de «los tundras* y encontramos ciertas variantes morfologicas, fonéticamente emparentadas con los referentes a los que aluden, porque debajo se esconden «los curas» y «los militares». Nombrar explícitamente determinadas realidades habria sido imposible; por eso utiliza estos enmascaramientos. Sin embargo, si los escritores fueron perfeccionando sus técnicas para disfrazar enunciados, los censores fueron aprendiendo a leer, a decodificar, y cada vez resultó más difícil saltarse las barreras ideologicas o de cualquier otro tipo.

2a CRUZ, Sabina de la: op.cit., Tomo II, 991. 
Sin embargo, y como hemos visto, funcionaron también otras artes para eludir las limitaciones de expresión, como las relaciones pertinentes, los premios que apoyaran y salvaguardaran una edición, las influencias exteriores, las editoriales o las colecciones específicas. Si no fuera porque este cuerpo de inspección cercenó y menoscabó muchas esperanzas, darían ganas de reírse. 